\title{
ADDITIVE MANUFACTURING IN ORTHODONTICS
}

\section{DODAJALNE TEHNOLOGIJE V ORTODONTIJI}

\author{
Anita Fekonja ${ }^{1}$, Nejc Rošer ${ }^{2}$, Igor Drstvenšek ${ }^{3}$ \\ ${ }^{1}$ University of Maribor, Faculty of Medicine, Taborska ulica 8, 2000 Maribor, Slovenia \\ ${ }^{2}$ Interesansa - Institute for Production Technologies and Development, Teslova ulica 27, 1000 Ljubljana, Slovenia \\ ${ }^{3}$ University of Maribor, Faculty of Mechanical Engineering, Smetanova ulica 17, 2000 Maribor, Slovenia
}

Prejem rokopisa - received: 2018-07-15; sprejem za objavo - accepted for publication: 2018-10-18

doi:10.17222/mit.2018.154

\begin{abstract}
In recent years, digitalization and Additive Manufacturing (AM) have opened new perspectives in the field of personalized complex medical and dental prostheses production and could be very useful also in orthodontics. Additively manufactured clear aligners for treating orthodontic malocclusions have been tested and evaluated. The treatment began with a three-dimensional scan of the patient's study cast and occlusion, followed by a treatment simulation using the software for the orthodontic planning and design of teeth models in a normal occlusion. The aligners were made from a thermoplastic polyurethane (TPU) foil by thermoforming it over the model made by laser sintering. The process has been tested and evaluated. Apart from the relatively well-known clear aligner treatment, a new appliance for the treatment of Class II malocclusions in growing patients has been developed. The fixed sagittal guidance (FSG) appliance is individually designed to fit on the upper molars. It consists of a crown and occlusal inclined plane. The crown has been designed using 3D dental design software and produced by selective laser melting (SLM) technology. After finishing the FSG is bonded on both upper molars. During closing of the jaw, the appliance provides guidance anteriorly and inferiorly to correct the sagittal and vertical deficiency in growing patients and produces favorable and measurable dentofacial and skeletal changes. These two different types of appliances represent the first use of additive manufacturing for orthodontic praxis in Slovenia. The results show the great potential and future perspectives of additive manufacturing in orthodontic treatment.
\end{abstract}

Keywords: additive manufacturing (AM), three-dimensional (3D), orthodontic appliance, malocclusion

V zadnjih letih sta digitalizacija in dodajalna tehnologija odprli nove možnosti na področju izdelave individualnih kompleksnih medicinskih in dentalnih pripomočkov. Dodajalna tehnologija je lahko zelo koristna tudi v ortodontiji zaradi kompleksne oblike zob in prilagojene proizvodnje aparatov. Za zdravljenje ortodontske malokluzije smo testirali prozorni zobni aparat, izdelan s postopkom dodajalnih tehnologij. Zdravljenje se je začelo s tridimenzionalnim skenom odlitka zob v okluziji. Sledila je simulacija zdravljenja $\mathrm{z}$ uporabo programske opreme za ortodontsko načrtovanje in izvoz STL modelov zob v normalni okluziji. Prozorni ortodontski aparati so bili izdelani iz termoplastične poliuretanske folije (TPU) s termoformiranjem preko modelov, izdelanih z laserskim sintranjem. Poleg relativno dobro znanega zdravljenja s prozornimi ortodontskimi aparati smo razvili novo vodilo za zdravljenje malokluzije razreda II pri odraščajočih pacientih. Fiksni aparat za sagitalno vodenje je individualno zasnovan tako, da se popolnoma prilega zgornjima zadnjima kočnikoma. Sestavljen je iz krone (kobalt-kromove zlitine) in okluzalno nagnjene ravnine, izdelane iz materiala SR Chromasit. Krona je bila zasnovana s 3D programsko opremo za zobne aplikacije in izdelana s tehnologijo selektivnega laserskega taljenja. Fiksni aparat za sagitalno vodenje vežemo na oba zgornja kočnika in med zapiranjem čeljusti vodi aparat spodnjo čeljust v pravilni sagitalni in vertikalni položaj pri odraščajočih pacientih. Ti dve različni vrsti aparatov predstavljata prvo praktično uporabo dodajalnih tehnologij v ortodontiji v Sloveniji. Rezultati kažejo velik potencial in perspektivo dodajalne tehnologije pri ortodontskem zdravljenju.

Ključne besede: dodajalne tehnologije, 3-dimenzionalno, ortodontski aparati, ortodontske nepravilnosti

\section{INTRODUCTION}

Additive Manufacturing (AM) is a common name for technologies that build 3D objects by adding material in a layer-by-layer form. The principle of layered production makes them very suitable for the low-volume production of parts with very complex shapes. The use of AM technologies requires a digital model of the part, an AM machine and a layering material. Once a CAD model is produced, the AM machine reads the data from the CAD file and lays down or adds successive layers of liquid, powder, sheet or other material, in a layer-uponlayer fashion to fabricate the 3D object. Because of its suitability for the low-volume production of complex parts, AM technology very soon found its way into

*Corresponding author e-mail:

anita.fekonja1@guest.arnes.si medical and especially dental applications. ${ }^{1-9}$ Until recently, orthodontic applications have been lagging behind, but with the newest research and applicable solutions ${ }^{10}$ it is becoming clear that AM technologies will also have to be considered in this field.

The clear aligner treatment is already well known in orthodontics, but it is limited to a small number of companies that offer this kind of service. AM machines make it possible to transfer the whole value chain of the clear aligner market into a single orthodontic laboratory if the work of a dental technician can be avoided. This is only possible if the whole workflow starts and finishes inside the computer program, which outputs the $3 \mathrm{D}$ data for the additive manufacturing of the final aligners. AM also opens new possibilities for curing malocclusions of different types. The fixed sagittal guidance (FSG) appliance promotes the growth of the lower jaw in 


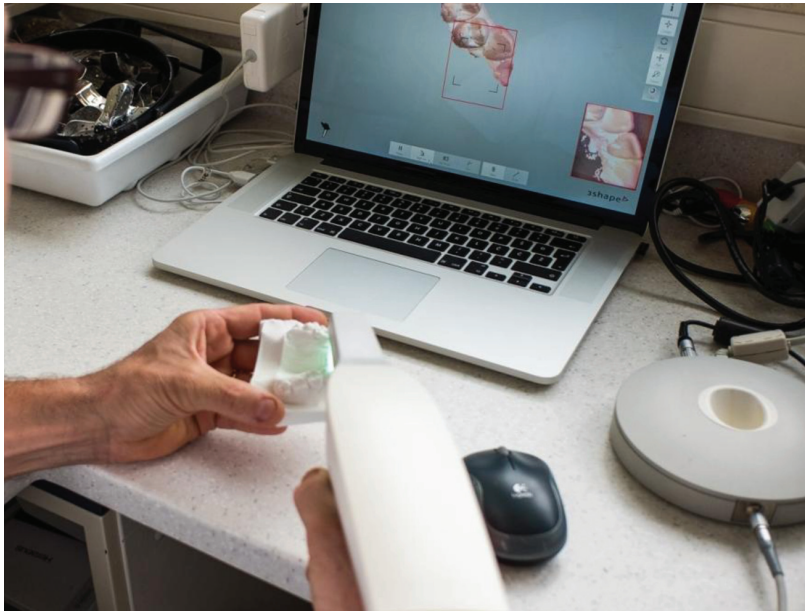

Figure 1: The working model is scanned with an intraoral scanner

patients with class II malocclusions. Using AM technologies and modern dental scanning and planning software the FSG appliance can be designed and produced between two sessions, thereby reducing the costs and the time required by the orthodontist. This review provides a brief discussion about the use of AM in orthodontics.

\section{EXPERIMENTAL PART}

In recent times, digitalization has played an important role in the manufacture of dental parts. In both appliances, the process began with a high-quality alginate impression of the upper and lower jaw for the working model. In next stage, the working model was scanned by an optical 3D scanner to obtain the data for the further digital workflow. Using an intraoral scanner, this part can be streamlined by avoiding the casting and scanning of the working model (Figure 1). But, even though, the whole process of optical scanning of the working models turned out to be at least as fast as the process of intraoral scanning. Regardless of the process for obtaining the digital data, the data need to be exported in the form of an exact virtual replica of the working model (Figure 2). The output file format is usually STL (Surface Tessellation Language).

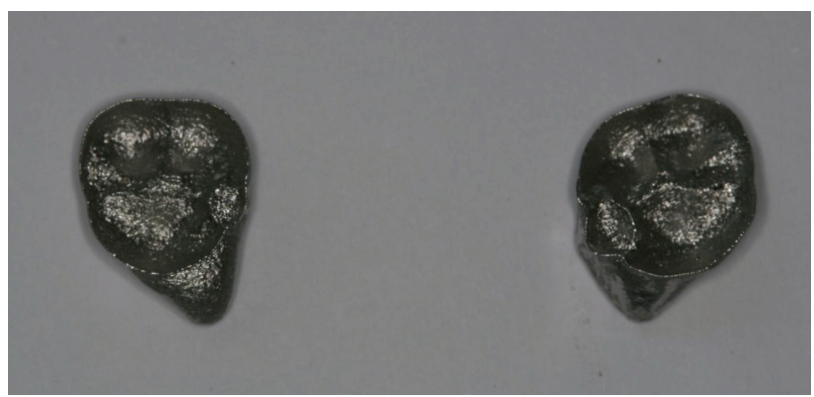

Figure 3: Crown of FMBG manufactured by selective laser melting (SLM) using Co-Cr alloy

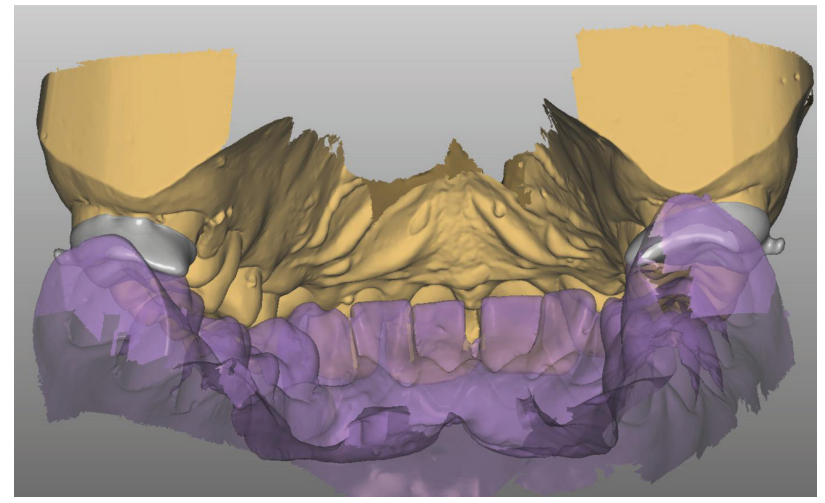

Figure 2: 3D virtual model

From this stage the manipulation of the virtual models and the production of these two appliances differs.

\subsection{Fixed sagittal guidance (FSG)}

The virtual model is processed by the dental software used for designing the fixed dental prosthetic elements. The crown of the FSG is modeled and then manufactured into the 3D part (crown of FSG) by selective laser melting (SLM) out of Co-Cr alloy (Figure 3). SLM is one of the AM technologies that uses a laser beam to melt powdered metal in a layer-by-layer manner. ${ }^{11}$ The resulting product metal crown of the FSG is very accurate, which ensured a perfect fit to the structure of the tooth. The crown is ready to be covered by the occlusal inclined plane made from SR Chromasit material (Ivoclar Vivadent, Figure 4).

The inclination of the inclined plane to the occlusal plane is individually designed according to the anatomical situation of the patient, thereby actively guiding the mandible anteriorly during jaw closure. It is individually made in the laboratory using an articulator. The construction of a wax bite is necessary for the production of the inclined plane. To register the bite for FSG manufacturing, the patient was asked to close his/her mouth in

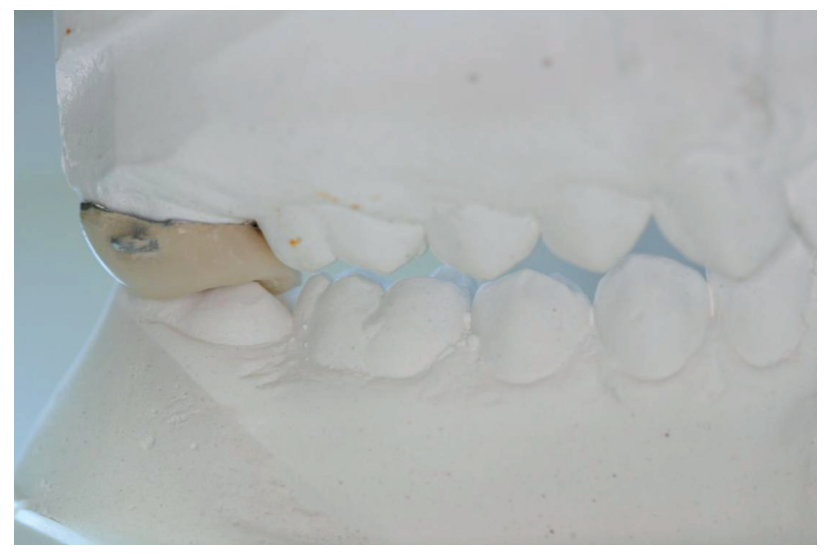

Figure 4: Crown covered by occlusal inclined plane made from SR Chromasit material (Ivoclar Vivadent) guides the mandible anteriorly during jaw closure 
the proper sagittal and vertical dimension. The inclination of the inclined plane can be adjusted in the laboratory depending on the specific case (severity of Class II relationship, deep bite).

\subsection{Clear aligner}

The virtual working model is imported into a software package for the orthodontic treatment planning and the design of the teeth models in a normal occlusion. Four different software packages were tested. All of them enable the manual movement of the teeth in the virtual jaw. In this way, the teeth are virtually moved into the ideal positions that should be achieved with the clear aligners treatment. The intermediate treatment stages (the positions of the teeth) are automatically computed and the virtual models of these stages are prepared for exporting. The number of stages varies depending upon the degree of irregularity. ${ }^{12}$ At this stage no significant differences have been found among the different orthodontic software packages. However, among the four packages only one enables the export of the STL model of the clear aligner; the other three only enable exporting of the model, which can be a serious shortcoming as the AM materials evolve. ${ }^{13}$ To export the aligners the software must provide an interface where the thickness and gum offset of the exported aligners can be adjusted. Conventionally, aligners are made from a thermoplastic polyurethane (TPU) foil (Figure 5) by thermoforming it over the model made by laser sintering (SLS).

The orthodontic forces and the moments generated by the thermoplastic aligners depend on the amount of activation ${ }^{14}$ and the material thickness. ${ }^{15}$ The results suggest that the activation of the lingual bodily movement of the maxillary central incisor should not exceed $0.5 \mathrm{~mm}$ and the initial $4 \mathrm{~d}$ or $5 \mathrm{~d}$ is important with respect to the orthodontic treatment incorporating an aligner. The technology has continued to improve clear

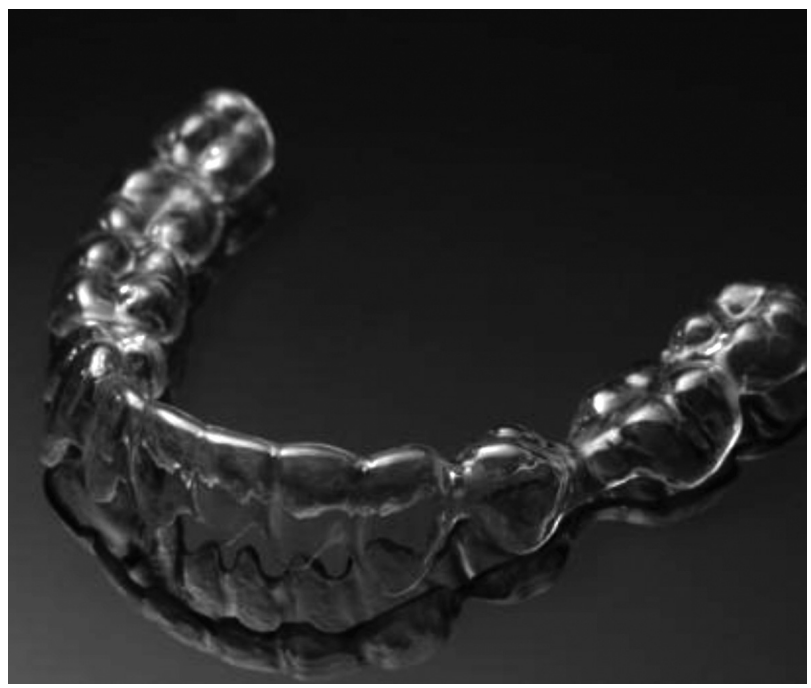

Figure 5: Thermoformed aligner aligner treatments since their inception. Replacing the impressions with increasingly more accurate intraoral scanners, 3D printing instead of plaster models, individual tooth movement and staging in virtual setups, and improvements in aligner materials and attachments are all examples of recent advances. ${ }^{16}$ During the research directly printed aligners (Figure 6) produced by stereolitography (SLA) were tested. Several photocuring resins that correspond to the medical devices directive 93/42/ECC for the production of Class IIa medical devices entered the market in recent years. By adjusting the thickness and post-curing process, these materials can be used to directly produce aligners. Directly printed aligners are cheaper to produce, but not as flexible as thermoplastic polyurethane foil and not so transparent. Once they are in the mouth mixed with saliva the visual difference is minimal.

\section{RESULTS}

\subsection{Fixed sagittal guidance (FSG)}

Patients with different severity of Class II malocclusion due to retrognathic mandible and deep bite were successfully treated using a FSG appliance made by SLM. The results were assessed through an analysis of the study cast and lateral cephalographs before and after treatment.

The study casts of all the patients after the treatment showed a Class I relationship, and a proper overbite and overjet. The analysis of the lateral cephalographs of all the patients after the treatment showed a skeletal Class I jaw relationship with the proper mandibular position, reduced facial convexity and increased lower anterior facial height (Table 1). The total improvement in the

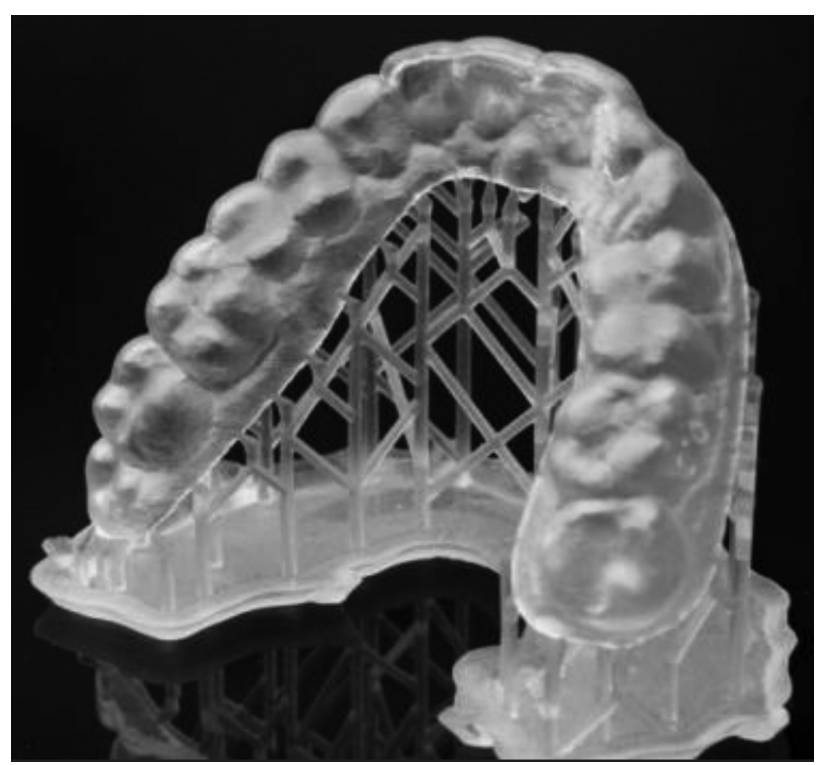

Figure 6: Directly printed aligner 
occlusal and soft-tissue relationships was the result of dental, skeletal and soft-tissue changes.

Table 1: Comparison of cephalometric variables between pre-treatment (T0) and post-treatment (T1) in patients treated with FSG

\begin{tabular}{|l|c|c|}
\hline \multicolumn{1}{|c|}{ Cephalometric variable } & T0 & T1 \\
\hline SNB $\left({ }^{\circ}\right)$ & 76 & 77.5 \\
\hline SNPg $\left({ }^{\circ}\right)$ & 78.5 & 79.5 \\
\hline ANB $\left({ }^{\circ}\right)$ & 3 & 2.5 \\
\hline Wits $(\mathrm{mm})$ & 4 & 2 \\
\hline SN/PL $\left(^{\circ}\right)$ & 7 & 6.5 \\
\hline SN/ML $\left({ }^{\circ}\right)$ & 26.5 & 31 \\
\hline LAFH $(m m)$ & 61 & 63.5 \\
\hline UAFH/LAFH (per cent) & 76.2 & 74.8 \\
\hline FH index (per cent) & 66.7 & 65.9 \\
\hline U1/PL $\left({ }^{\circ}\right)$ & 113 & 108 \\
\hline L1/ML $\left(^{\circ}\right)$ & 93 & 93.5 \\
\hline Overbite $(\mathrm{mm})$ & 6.5 & 2.5 \\
\hline Overjet $(\mathrm{mm})$ & 7 & 3 \\
\hline
\end{tabular}

\subsection{Clear aligner}

Clear aligner treatment (CAT) is an effective procedure that can align and level the arches in non-growing subjects. The anterior intrusion movement achievable with CAT is comparable to that reported for the straightwire technique, but it is not effective in controlling the anterior extrusion movement. Contrasting results have been reported in relation to the posterior vertical control, and a definite conclusion cannot be drawn. CAT is not effective in controlling rotations, especially those of rounded teeth. In this case, attachments are necessary. It is effective in controlling the posterior but not the anterior buccolingual inclination. CAT is effective in controlling the upper molar bodily movement when a distalization of $1.5 \mathrm{~mm}$ has been prescribed. CAT is not based on aligners alone; it requires the use of auxiliaries (attachments, interarch elastics, IPR, altered aligner geometries) to improve the predictability of the orthodontic movement. ${ }^{17}$ Simple cases have been successfully treated, typical for treating with clear aligners. Treating more complicated cases, such as open bite, is harder to achieve and includes the use of auxiliaries.

\section{DISCUSSION}

Freedom of design, mass customization, waste minimization and the ability to manufacture complex structures, as well as fast prototyping, are the main benefits of Additive Manufacturing (AM). In recent years, digitalization and Additive Manufacturing (AM) have opened new perspectives in the field of personalized complex medical and dental prostheses production. ${ }^{18}$ AM could also be very useful in orthodontics because of the complex shape of teeth and the customized production of appliances. $^{2-10}$

The FSG appliance is completely individually designed for patients with a Class II relationship due to a retrognathic mandible. The FSG appliance, in closing the jaw, guides the mandible anteriorly and inferiorly to correct the sagittal and vertical deficiency, which achieved an increase in the mandibular length and the forward and downward movement of the mandible.

The function of the FSG appliance is similar to elastic and flexible fixed units (Jasper jumper, Herbst appliance) but without an influence on the lower incisors' proclination, reported by Pancherz, ${ }^{19}$ Stucki and Ingervall, ${ }^{20}$ Weiland et al., ${ }^{21}$ Gohilot et al., ${ }^{22}$ Neves et $a l .{ }^{23}$ So, the FSG is ideal in the case of proclined incisors, because there is a great need to control the incisor inclination.

Using the FSG appliance, the upper and lower jaw are not connected, which allows the patient to open the mouth fully and all the functional movements are almost frictionless. Other fixed units (Jusper jumper, Herbst appliance) connect the upper and lower jaws together and therefore somewhat restrict the jaw's movement.

A deep bite due to an excessive curve of the Spee often accompanies a Class II malocclusion. With the FSG appliance it is possible to level an excessive curve of the Spee in the lower arch. The presented research identified a decrease in the overbite due to leveling of the Spee curve and a mandibular downward rotation.

FSG enables the concomitant use of a palatal arch in the case of a narrow upper jaw, which is an additional advantage of this method of treatment.

CAs are designed for each person individually. One of the advantages of using the $\mathrm{CA}$ is the ability to selectively orchestrate the dental movements. The velocities of every tooth can be dictated and monitored as the treatment is planned and executed. Periodontally compromised teeth can also be almost left stationary during the treatment with minimum and/or no mechanical pressure.

Teeth are not $100 \%$ predictable, so overcorrections are necessary. During the research, an approximately $70 \%$ predictability can be certified.

This method of treatment for simple cases is equally effective as conventional fixed appliances. Conventional fixed appliances have been more effective in malocclusion treating, but treating with clear aligners is $30 \%$ faster $^{24}$ and they are barely visible.

CAs are easy to remove, and hence do not interfere with maintaining hygiene. They are transparent and do not interfere with speech.

\section{CONCLUSIONS}

In a treatment with a digital and fast procedure in patients with Class II malocclusion due to a retrognathic mandible, the results for the patients are promising, although long-term results are not yet available.

Over the past 16 years, CA treatment has developed from a technique for only treating mild crowding or the spacing of anterior teeth to a technique that can be used to treat almost any type of orthodontic problem. How- 
ever, to do so, it is important to understand the limitations of the appliance and to be able to think "out of the box" in treatment planning. Aligner materials and attachments will continue to improve, which will allow aligners to fit better and for longer periods of time and result in better outcomes.

\section{Acknowledgment}

The authors would like to thank the Healthcare Centre Maribor, Slovenia, for technical manufacturing of the FSG and CA.

\section{REFERENCES}

${ }^{1}$ I. Drstvenšek, Pregled uporabe dodajalne izdelave v dentalni medicine, Zbornik prispevkov 22. simpozija Sekcije za stomatološko protetiko Slovenskega zdravniškega društva, Ljubljana, 2017, 26-42

${ }^{2}$ I. Budak, B. Kosec, M. Sokovic, Application of contemporary engineering techniques and technologies in the field of denta prosthetics, Journal of Achievements in Materials and Manufacturing Engineering 54 (2012) 2, 233-241

${ }^{3}$ T. Brajlih, B. Valentan, J. Balič, I. Drstvenšek, Speed and accuracy evaluation of additive manufacturing machines, Rapid prototyping journal, 17 (2010) 1, 64-75, doi:10.1108/RPJ-10-2016-0163

${ }^{4}$ I. Drstvenšek, T. Brajlih, M. Paulič, J. Balič, T. Tomažič, Patient specific instruments for total hip replacement surgery, Academic Journal of Manufacturing Engineering, 11 (2013) 4, 6-9

${ }^{5}$ M. Merc, I. Drstvenšek, M. Vogrin, T. Brajlih, T. Friedrich, G. Rečnik, Error rate of multi-level rapid prototyping trajectories for pedicle screw placement in lumbar and sacral spine, Chinese journal of traumatology, 17 (2014) 5, 261-266, doi:10.3760/cma.j.issn. 1008-1275.2014.05.003

${ }^{6}$ I. Drstvenšek, N. Ihan Hren, T. Strojnik, T. Brajlih, B. Valentan, V. Pogačar, T. Zupančič Hartner, Applications of rapid prototyping in cranio-maxilofacial surgery procedures, International journal of biology and biomedical engineering, 2 (2008) 1, 29-38

${ }^{7}$ M. Merc, I. Drstvenšek, M. Vogrin, T. Brajlih, G. Rečnik, A multilevel rapid prototyping drill guide template reduces the perforation risk of pedicle screw placement in the lumbar and sacral spine, Archives of orthopaedic and trauma surgery, 133 (2013) 7, 893-899, doi:10.1007/s00402-013-1755-0

${ }^{8}$ S. Benazzi, S. Senck S, Comparing 3-dimensional virtual methods for reconstruction in cranio-maxillofacial surgery, J Oral Maxillofac Surg., 69 (2011) 4, 1184-94, doi:10.1016/j.joms.2010.02.028

${ }^{9}$ D. Jevremović, V. Kojić, G. Bogdanović, T. Puškar, D. Eggbeer, D. Thoma et al, A selective laser melted $\mathrm{Co}-\mathrm{Cr}$ alloy used for the rapid manufacture of removable partial denture frameworks - initial screening of biocompatibility, J Serb Chem Soc., 76 (2011) 1, 43-52, doi:10.2298/JSC100406014J

${ }^{10}$ A. Fekonja, A. Čretnik, T. Zupancic Hartner, Mandibular retrognathia correction using a fixed sagittal guidance appliance individually manufactured by Selective Laser Melting manufacturing technology, Rapid Prototyping Journal, 24 (2018) 2, 416-423, doi:10.1108/RPJ-10-2016-0163

${ }^{11}$ J. P. Kruth, P. Mercelis, J. Van Vaerenbergh, L. Froven, M. Rombouts, Binding mechanisms in selective laser sintering and selactive laser melting, Rapid Prototyping Journal 11 (2005) 1, 26-36, doi:10.1108/13552540510573365

${ }^{12}$ J. Morton, BSE, M. Derakhshan, S. Kaza, C. Li, Design of the Invisalign system performance, Elsevier Inc, 2017, 3-11

${ }^{13}$ N. Rošer, Postopki izdelave ortodontskega aparata $\mathrm{z}$ dodajalnimi tehnologijami (magistrsko delo), Maribor, 2018

${ }^{14}$ X. Li, C. Ren, Z. Wang, P. Zhao, H. Wang, Y. Bai, Changes in force associated with the amount of aligner activation and lingual odily movement of the maxillary central incisor, Korean J. Orthod, 46 (2016) 2, 65-72, doi:10.4041/kjod.2016.46.2.65

${ }^{15}$ L. Liu, B. He, J. Zhuang, L. Zhang, A. Lv, Force measurement system for invisalign based on thin film single force sensor, Measurement, 97 (2016) 1-7, doi:10.1016/j.measurement.2016.11.018

${ }^{16} \mathrm{~J}$. S. Browman, Improving the predictability of clear aligners, Semin Orthod 23 (2017) 1, 65-75, doi:10.1053/j.sodo.2016.10.005

${ }^{17}$ G. Rossini, S. Parrini, T. Castroflorio, A. Deregibus, LC. Debernandi, Efficacy of clear aligners in controlling orthodontic tooth movement: A systematic review, Angle Orthod, 85 (2015) 5, 881-889, doi:10.2319/061614-436.1

${ }^{18}$ TD. Ngo, A. Kashani, G. Imbalzano, KTO. Nguyen, D. Hui, Additive manufacturing (3D printing): A review of materials, methods, applications and challenges, Engeneering, 143 (2018) 172-196, doi:10.1016/j.compositesb.2018.02.012

${ }^{19} \mathrm{H}$. Pancherz, The mechanism of Class II correction in Herbst appliance treatment, A cephalometric investigation, Am J Orthod., 82 (1992) 2, 104-113

${ }^{20}$ F. J. Weiland, B. Ingervall, H. P. Bantleon, H. Droacht, Initial effects of treatment of Class II malocclusion with the Herren activator, activator-headgear combination and the Jasper Jumpe, Am J Orthod Dentofac Orthoped. 112 (1997) 1, 19-27

${ }^{21}$ N. Stucki, B. Ingervall, The use of the Jasper Jumper for the correction of the Class II malocclusion in the young permanent dentition, Europ J Orthod., 20 (1998) 3, 271-281

${ }^{22}$ A. Gohilot, T. Pradhan, K. M. Keluskar, Comparison of dentoskeletal and soft tissue changes seen In Class II division I malocclusion using Forsus $^{\mathrm{TM}}$ fatigue resistant device, Churro Jumper and Herbst appliance - a randomized clinical trial, The Orthodontic Cyber Journal, (2013)

${ }^{23}$ L. S. Neves, G. Janson, R. H. Cancado, K. T. de Lima, T. M. Fernandes, J. F. Henriques, Treatment effects of the Jasper Jumper and the Bionator associated with fixed appliances, Progress in Orthodontics, 15 (2014) 1, 54-59, doi:10.1186/s40510-014-0054-9

${ }^{24}$ J. Gu, J. J. S. Tang, B. Skulski, H. W. Fields Jr, F. M. Beck, A. R. Firestone, D. G. Kim, T. Deguchia, Evaluation of Invisalign treatment effectiveness and efficiency compared with conventional fixed appliances using the Peer Assessment Rating index, Am J Orthod Dentofacial Orthoped., 151 (2017), 259-266, doi:10.1016/j.ajodo. 2016.06.041 